\title{
Monoclonality and cytogenetic abnormalities in hyaline vascular Castleman disease
}

Kung-Chao Chang ${ }^{1}$, Yu-Chu Wang 2,7 , Liang-Yi Hung ${ }^{2,7}$, Wan-Ting Huang 3,7 , Jen-Hui Tsou ${ }^{2,8}$, Dan M Jones ${ }^{4}$, Hsiang-Lin Song ${ }^{1}$, Yu-Min Yeh ${ }^{5}$, Lin-Yuan Kao ${ }^{1}$ and L Jeffrey Medeiros ${ }^{6}$

${ }^{1}$ Department of Pathology, College of Medicine, National Cheng Kung University and Hospital, Tainan, Taiwan; ${ }^{2}$ Institute of Bioinformatics and Biosignal Transduction, College of Bioscience and Biotechnology, National Cheng Kung University, Tainan, Taiwan; ${ }^{3}$ Department of Pathology, Chang Gung Memorial Hospital-Kaohsiung Medical Center, Chang Gung University College of Medicine, Kaohsiung, Taiwan; ${ }^{4}$ School of Medicine, The University of Texas Anderson Cancer Center, Houston, TX, USA; ${ }^{5}$ Department of Internal Medicine, College of Medicine, National Cheng Kung University and Hospital, Tainan, Taiwan and ${ }^{6}$ Department of Hematopathology, The University of Texas MD Anderson Cancer Center, Houston, TX, USA

\begin{abstract}
Hyaline vascular Castleman disease is traditionally regarded as a reactive hyperplastic process. Occasional cases, however, have been reported with cytogenetic anomalies bringing this concept into question. In this study, we used conventional and methylation-specific polymerase chain reaction methods to assess the human androgen receptor $\alpha$ (HUMARA) gene in 29 female patients with hyaline vascular Castleman disease and compared the results with three cases of plasma cell Castleman disease and 20 cases of age-matched lymphoid hyperplasia. We also assessed for immunoglobulin gene and T-cell receptor gene rearrangements, and conventional cytogenetic analysis was performed in three cases of hyaline vascular Castleman disease. In cases with informative results, conventional and methylation-specific human androgen receptor $\alpha$ gene analyses yielded a monoclonal pattern in 10 of $19(53 \%)$ and 17 of $23(74 \%)$ cases of hyaline vascular Castleman disease, respectively. A monoclonal pattern was also detected in three cases of plasma cell Castleman disease but not in cases of lymphoid hyperplasia. The frequency of monoclonality was higher for lesions $>5 \mathrm{~cm}$ in size (100\%) and for the stromal-rich variant (91\%). Cytogenetic abnormalities in stromal cells were revealed in two cases of hyaline vascular Castleman disease and no cases showed monoclonal immunoglobulin or T-cell receptor gene rearrangements. Follow-up data showed persistent disease in 4 of $23(17 \%)$ patients. We conclude that hyaline vascular Castleman disease is often a monoclonal proliferation, most likely of lymph node stromal cells. Modern Pathology (2014) 27, 823-831; doi:10.1038/modpathol.2013.202; published online 8 November 2013
\end{abstract}

Keywords: cytogenetic abnormalities; human androgen receptor $\alpha$ gene; hyaline vascular Castleman disease; monoclonal proliferation; stromal cells

In 1956, Castleman et $a l^{1}$ described the hyaline vascular variant of Castleman disease as a large, benign, asymptomatic mass involving mediastinal lymph nodes. Castleman disease has also been designated as 'angiofollicular lymph node hyper-

Correspondence: Dr K-C Chang, MD, PhD, Department of Pathology, College of Medicine, National Cheng Kung University Hospital, 138 Sheng-Li Road, Tainan 704, Taiwan or Dr LJ Medeiros, MD, Department of Hematopathology, Unit 72, The University of Texas MD Anderson Cancer Center, 1515 Holcombe Boulevard, Houston, TX 77030, USA.

E-mail: changkc@mail.ncku.edu.tw or ljmedeiros@mdanderson.org ${ }^{7}$ These authors contributed equally to this work.

${ }^{8}$ Current address: Graduate Institute of Medical Science, College of Medicine, Taipei Medical University, Taipei, Taiwan.

Received 4 July 2013; accepted 31 July 2013; published online 8 November 2013 plasia' or 'giant cell lymph node hyperplasia.' Subsequently, Castleman and co-workers ${ }^{2}$ expanded the concept to include plasma cell variant cases and others recognized multicentric disease and the role of human herpes virus 8 (HHV-8) in some cases. ${ }^{3-5}$ Recent studies have focused on the pathogenetic role of overexpression of interleukin-6, a B-lymphocyte stimulator, and subsequent plasma cell proliferations in plasma-cell-type and multicentric Castleman disease. ${ }^{6,7}$ However, the etiology of hyaline vascular variant remains unclear and there are limited studies regarding this issue.

Hyaline vascular Castleman disease, the most common form of Castleman disease, is characterized clinically by a solitary, slow-growing mass, most typically in the mediastinum or neck, without associated constitutional symptoms. ${ }^{8}$ The histological 
features characteristic of hyaline vascular Castleman disease are abnormal, lymphocyte-depleted follicles with sclerotic radial arterioles, vessel-rich interfollicular tissues, and compressed or absent subcapsular sinuses. Hyaline vascular Castleman disease is traditionally regarded as a hyperplastic or reactive process and surgical excision is adequate for treatment for most patients. ${ }^{5,9}$

In addition to characteristic follicular changes, overgrowth of stromal cells in hyaline vascular Castleman disease is a well-documented phenomenon. ${ }^{10}$ Although stromal overgrowth is usually considered secondary, several authors have stressed the possible pathogenetic role of dysplastic follicular dendritic cells in this disorder. ${ }^{11-13}$ Furthermore, there are emerging data demonstrating clonal cytogenetic abnormalities in stromal cells of hyaline vascular Castleman disease without overt stromal cell overgrowth. Pauwels et al ${ }^{14}$ reported a case of hyaline vascular Castleman disease with dysplastic follicular dendritic cells associated with a clonal $\mathrm{t}(1 ; 16)(\mathrm{p} 11 ; \mathrm{p} 11) .{ }^{14}$ Cokelaere et $a 1^{15}$ described another case of hyaline vascular Castleman disease and showed HMGIC gene rearrangement in follicular dendritic cells of the lesion by combined immunofluorescence and FISH analysis. In a previous report of hyaline vascular Castleman disease, we showed stromal cells that had features of myoid cells in short-term culture associated with a clonal $\mathrm{t}(1 ; 22)(\mathrm{p} 22 ; \mathrm{q} 13) .{ }^{16}$ The finding of genetic anomalies in hyaline vascular Castleman disease suggests that it is a monoclonal proliferation.

In this study, we have analyzed the human androgen receptor $\alpha$ (HUMARA) gene in female patients with hyaline vascular Castleman disease to assess for monoclonality. Our results suggest that hyaline vascular Castleman disease is commonly a monoclonal lesion, most likely arising in lymph node stromal cells.

\section{Materials and methods}

\section{Female Cases of Hyaline Vascular Castleman Disease}

Female patients with hyaline vascular Castleman disease were enrolled from the archival files of National Cheng Kung University Hospital, Taiwan (N1-N12), the MD Anderson Cancer Center, USA (M1-M7), and Chang Gung Memorial HospitalKaohsiung Medical Center (C1-C13). Studies were carried out under a laboratory protocol approved by our institutional review board (NCKUH-BR-99-116C) and were in accordance with the Declaration of Helsinki of 1975, as revised in 1983. The diagnosis was reviewed by three hematopathologists and the hyaline vascular Castleman disease cases were further subclassified as classical, lymphoid, ${ }^{8}$ and stromal-rich variant. ${ }^{9,11}$ The classical cases of hyaline vascular Castleman disease showed regressed and confluent follicles with radially penetrating sclerotic arterioles ('lollipop lesion'), hyaline deposits in germinal centers, concentric layering of mantle zone lymphocytes ('onion skin appearance'), inapparent sinuses, and interfollicular vascular hyperplasia (Figures $1 \mathrm{a}$ and $\mathrm{b}$ ). The lymphoid variant was characterized by mantle zone expansion around the atrophic, inconspicuous germinal center that may mimic follicular lymphoma or mantle cell lymphoma (Figure 1c). The stromal-rich variant was defined as a prominent interfollicular zone occupying $50 \%$ or more of the nodal area. ${ }^{11}$ The interfollicular zones had increased stromal cells and blood vessels and were associated with residual lymphoid follicles (Figure 1d). The frequent components of stromal cells were actinpositive 'myoid' cells and follicular dendritic cells. No clinical evidence of IgG4-related diseases or lymphoma association was noted. For comparison, three cases of plasma-cell-type Castleman disease (N8, M2, and C4) and 20 cases of lymphoid hyperplasia (LH1-LH20) were included. All specimens were fixed in 10\% neutral formalin and embedded in paraffin. Clinical data and follow-up information were obtained by chart review.

\section{Histological and Immunohistochemical Stains}

Hematoxylin and eosin (H\&E) stain and immunohistochemical (IHC) studies were performed on formalin-fixed, paraffin-embedded tissue sections. IHC analysis was performed on 4- $\mu$ m-thick sections with a mouse anti-HHV-8 (1:50 dilution; Novocastra, Leica Biosystems Newcastle, Melbourne, Australia) as the primary antibody after tissues were deparaffinized with xylene and pretreated with the Epitope Retrieval Solution 2 (EDTA, pH 9.0). The procedures were carried out with the Bond-Max Automated IHC stainer (Leica Biosystems Newcastle). Counterstaining was carried out with hematoxylin.

\section{Conventional HUMARA Gene Assay and HUMARA Methylation-Specific Polymerase Chain Reaction}

Genomic DNA from ten 8- $\mu$ m-thick sections of paraffin-embedded, formalin-fixed tissues was isolated with the QIAamp genomic DNA kit (Qiagen, Studio City, CA, USA) according to the manufacturer's instructions. Only tissues involved by Castleman disease were sectioned. Erdheim-Chester disease and peripheral blood mononuclear cells were used as positive and negative controls, respectively, as our previous study. ${ }^{17}$ The clonality analysis was performed by conventional HUMARA and methylation-specific polymerase chain reaction (PCR) HUMARA.

For conventional HUMARA, ${ }^{17,18}$ aliquots of $25 \mathrm{ng}$ of HhaI-digested or -undigested genomic DNA were amplified with primers (HUMARA 1A, 5'-AGG TGGAAGATTCAGCCAAG-3'; and HUMARA 1B, 

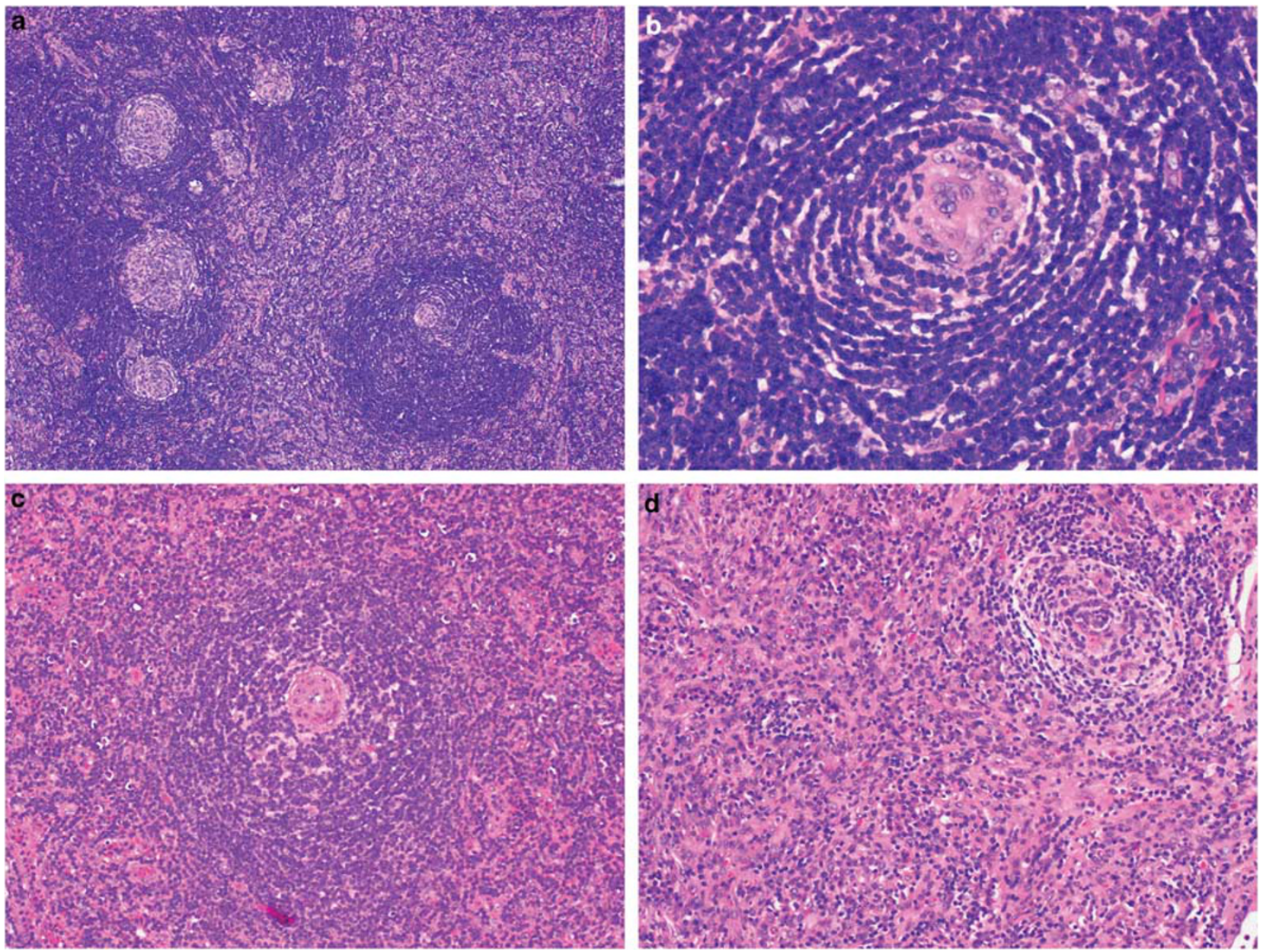

Figure 1 Pathologic features of Castleman disease. The classical type of hyaline vascular Castleman disease shows lymphoid hyperplasia with a broad mantle zone and interfollicular vascular hyperplasia. (a) In this case, the expanded mantle zone contains multiple pale germinal centers (left, $\times 40$ ). The interfollicular regions contain many high-endothelial venules with sclerotic walls (right upper). (b) The germinal center is atrophic, depleted of follicular center cells, and surrounded by concentrically arranged small lymphocytes imparting an 'onion-skin' pattern $(\times 200)$. (c) This case $(\mathrm{N} 1)$ of lymphoid variant shows mantle zone expansion around the atrophic, inconspicuous germinal center that may mimic follicular lymphoma or mantle cell lymphoma $(\times 100)$. These expanded cells are negative for bcl-6, CD10, and cyclin D1 as well as immunoglobulin gene rearrangement. Other clues leading to the right diagnosis include small vessels in germinal centers reminiscent of central arteries of spleen and prominent vasculature in the paracortical zone. (d) This case (N7) of stromal-rich variant shows 'angiomyoid' proliferations composed of hyperplastic spindle cells and blood vessels in interfollicular area with a residual lymphoid follicle (right upper, $\times 100$ ). The plump spindle cells possess blunt nuclei and are positive for smooth muscle actin but negative for CD21, CD34, S-100, or CD68.

$5^{\prime}$-TGTGAAGGTTGCTGTTCCTC-3') in a $20 \mu \mathrm{l}$ of PCR mixture. All samples were digested with HhaI for at least $3 \mathrm{~h}$. The XE169 gene fold reduction was measured to monitor the efficiency of restriction enzyme digestion as described previously. ${ }^{19}$ After $10 \mathrm{~min}$ of denaturation at $95^{\circ} \mathrm{C}$, PCRs were then perfomed using the following conditions for 45 cycles: $95{ }^{\circ} \mathrm{C}$ for $30 \mathrm{~s}, 55^{\circ} \mathrm{C}$ for $30 \mathrm{~s}$, and $72{ }^{\circ} \mathrm{C}$ for $30 \mathrm{~s}$. PCR products were electrophoresed on a $11 \%$ acrylamide gel and visulaized by staining with ethidium bromide.

For methylation-specific PCR HUMARA analysis, ${ }^{20} 500 \mathrm{ng}$ of DNA was modified with sodium bisulfate by EpiTect Fast DNA Bisulfide kit (Qiagen) according to the manufacturer's instructions. Aliquots of $25 \mathrm{ng}$ of modified DNA were subjected to PCR in a total of $20 \mu \mathrm{l}$ mixture with primers specific for unmethylated (U: US2, 5'-GGTTGTGAG TGTAGTATTTTTTGGT-3'; and HUMARA 1B) or methylated (M: MS2, 5'-CGAGCGTAGTATTTTTCG GC-3'; and HUMARA 1B) DNA. After denaturation at $95{ }^{\circ} \mathrm{C}$ for $10 \mathrm{~min}$, PCRs were perfomed using the following conditions for 45 cycles: $95^{\circ} \mathrm{C}$ for $45 \mathrm{~s}$, $55^{\circ} \mathrm{C}$ for $45 \mathrm{~s}$, and $72{ }^{\circ} \mathrm{C}$ for $60 \mathrm{~s}$. PCR products of methylation-specific HUMARA were analyzed on a $1.8 \%$ agarose gel and visualized by staining with ethidium bromide.

\section{PCR Studies for B- and T-Cell Clonality}

To detect possible monoclonal proliferations of lymphoid cells, the BIOMED-2 protocols were performed from paraffin blocks for the rearrangement of immunoglobulin heavy- and light-chain 
Table 1 Clinicopathologic data of 32 female cases of Castleman disease including 29 hyaline vascular and 3 plasma cell types

\begin{tabular}{|c|c|c|c|c|c|c|c|c|c|}
\hline \multirow[b]{2}{*}{$\begin{array}{l}\text { Case } \\
\text { no. }\end{array}$} & \multirow[b]{2}{*}{$\begin{array}{c}\text { Age } \\
\text { (years) }\end{array}$} & \multirow[b]{2}{*}{ Lesion site } & \multirow[b]{2}{*}{ Castleman disease subtype } & \multirow[b]{2}{*}{ Size $(\mathrm{cm})$} & \multicolumn{3}{|c|}{ HUMARA analysis } & \multirow[b]{2}{*}{$\begin{array}{l}\text { Immuno- } \\
\text { globulin } \\
\text { gene }\end{array}$} & \multirow[b]{2}{*}{$\begin{array}{l}\text { T-cell } \\
\text { receptor } \\
\text { gene }\end{array}$} \\
\hline & & & & & Conv & $\begin{array}{l}\text { Methylation- } \\
\text { specific PCR }\end{array}$ & Overall & & \\
\hline N1 & 59 & Right buccal & $\begin{array}{l}\text { Hyaline vascular, lymphoid } \\
\text { variant }\end{array}$ & 2.5 & M & $\mathrm{M}$ & M & $\mathrm{P}$ & $\mathrm{P}$ \\
\hline N2 & 43 & Left retroperitoneal & Hyaline vascular, stromal-rich & 11.0 & $\mathrm{M}$ & NI & $\mathrm{M}$ & $\mathrm{P}$ & $\mathrm{P}$ \\
\hline N3 & 12 & Right neck & Hyaline vascular, classic & 4.0 & $\mathrm{P}$ & NI & $\mathrm{P}$ & $\mathrm{P}$ & $\mathrm{P}$ \\
\hline N4 & 21 & Left neck & $\begin{array}{l}\text { Hyaline vascular, lymphoid } \\
\text { variant }\end{array}$ & 4.0 & $\mathrm{P}$ & NI & $\mathrm{P}$ & $\mathrm{P}$ & $\mathrm{P}$ \\
\hline N5 & 12 & Left neck & $\begin{array}{l}\text { Hyaline vascular, lymphoid } \\
\text { variant }\end{array}$ & 5.0 & NI & $\mathrm{M}$ & M & $\mathrm{P}$ & $\mathrm{P}$ \\
\hline N6 & 5 & Left neck & Hyaline vascular, classic & 1.5 & NI & $\mathrm{M}$ & $\mathrm{M}$ & $\mathrm{P}$ & $\mathrm{P}$ \\
\hline N7 & 45 & Left retroperitoneal & $\begin{array}{l}\text { Hyaline vascular, stromal-rich, } \\
\text { with 'angiomyoid' } \\
\text { proliferations }\end{array}$ & 5.0 & M & $\mathrm{P}$ & M & $\mathrm{P}$ & $\mathrm{P}$ \\
\hline N8 & 55 & Mesenteric & Plasma cell type & 4.0 & $\mathrm{M}$ & M & $\mathrm{M}$ & $\mathrm{P}$ & $\mathrm{P}$ \\
\hline N9 & 65 & Retroperitoneum & Hyaline vascular, stromal-rich & 5.9 & $\mathrm{M}$ & $\mathrm{P}$ & $\mathrm{M}$ & $\mathrm{P}$ & $\mathrm{P}$ \\
\hline N10 & 36 & Liver hilum & Hyaline vascular, stromal-rich & 2.3 & $\mathrm{P}$ & $\mathrm{P}$ & $\mathrm{P}$ & $\mathrm{P}$ & $\mathrm{P}$ \\
\hline N11 & 19 & Posterior mediastinum & Hyaline vascular, classic & 5.1 & $\mathrm{M}$ & $\mathrm{M}$ & $\mathrm{M}$ & $\mathrm{P}$ & $\mathrm{P}$ \\
\hline N12 & 29 & Mediastinum & Hyaline vascular, stromal-rich & 7.5 & $\mathrm{P}$ & $\mathrm{M}$ & $\mathrm{M}$ & $\mathrm{P}$ & $\mathrm{P}$ \\
\hline M1 & 40 & Left axillary & Hyaline vascular, classic & NA & $\mathrm{P}$ & NI & $\mathrm{P}$ & $\mathrm{P}$ & $\mathrm{P}$ \\
\hline M2 & 39 & Mediastinum & Plasma cell type & NA & NI & $\mathrm{M}$ & $\mathrm{M}$ & $\mathrm{P}$ & $\mathrm{P}$ \\
\hline M3 & 49 & Neck & $\begin{array}{l}\text { Hyaline vascular, stromal-rich, } \\
\text { with 'angiomyoid' } \\
\text { proliferations }\end{array}$ & NA & M & $\mathrm{P}$ & $\mathrm{M}$ & $\mathrm{P}$ & $\mathrm{P}$ \\
\hline M4 & 45 & Arm & Hyaline vascular, classic & NA & NI & $\mathrm{M}$ & $\mathrm{M}$ & $\mathrm{P}$ & $\mathrm{P}$ \\
\hline M5 & 35 & Supraclavicular & Hyaline vascular, classic & NA & NI & M & $\mathrm{M}$ & $\mathrm{P}$ & $\mathrm{P}$ \\
\hline M6 & 61 & Porta hepatis & Hyaline vascular, classic & NA & NI & $\mathrm{M}$ & $\mathrm{M}$ & $\mathrm{P}$ & $\mathrm{P}$ \\
\hline M7 & 25 & Pelvic & $\begin{array}{l}\text { Hyaline vascular, with } \\
\text { follicular dendritic cell } \\
\text { sarcoma }\end{array}$ & NA & NI & M & $\mathrm{M}$ & $\mathrm{P}$ & $\mathrm{P}$ \\
\hline C1 & 21 & Mediastinum & Hyaline vascular, stromal-rich & 7.5 & $\mathrm{P}$ & $\mathrm{M}$ & $\mathrm{M}$ & $\mathrm{P}$ & $\mathrm{P}$ \\
\hline $\mathrm{C} 2$ & 24 & Mediastinum & Hyaline vascular, stromal-rich & 7.0 & NI & NI & NI & $\mathrm{P}$ & $\mathrm{P}$ \\
\hline C3 & 45 & Retroperitoneum & Hyaline vascular, classic & 6.5 & $\mathrm{M}$ & $\mathrm{P}$ & $\mathrm{M}$ & $\mathrm{P}$ & $\mathrm{P}$ \\
\hline $\mathrm{C} 4$ & 27 & Pancreaticoduodenal & Plasma cell type & 4.0 & $\mathrm{M}$ & $\mathrm{M}$ & $\mathrm{M}$ & $\mathrm{M}$ & $\mathrm{P}$ \\
\hline C5 & 31 & Left neck & Hyaline vascular, classic & 8.0 & $\mathrm{M}$ & M & $\mathrm{M}$ & $\mathrm{P}$ & $\mathrm{P}$ \\
\hline C6 & 48 & Right neck & Hyaline vascular, classic & 2.2 & $\mathrm{P}$ & $\mathrm{M}$ & $\mathrm{M}$ & $\mathrm{E}$ & $\mathrm{P}$ \\
\hline C7 & 8 & Mediastinum & Hyaline vascular, classic & 5.0 & NI & $\mathrm{P}$ & $\mathrm{P}$ & $\mathrm{P}$ & $\mathrm{P}$ \\
\hline C8 & 37 & Left neck & $\begin{array}{l}\text { Hyaline vascular, lymphoid } \\
\text { variant }\end{array}$ & 1.6 & $\mathrm{P}$ & M & M & $\mathrm{P}$ & $\mathrm{P}$ \\
\hline C9 & 31 & Left neck & Hyaline vascular, stromal-rich & 4.0 & $\mathrm{M}$ & $\mathrm{M}$ & $\mathrm{M}$ & $\mathrm{P}$ & $\mathrm{P}$ \\
\hline C10 & 19 & Left neck & Hyaline vascular, classic & 4.1 & $\mathrm{M}$ & $\mathrm{M}$ & $\mathrm{M}$ & $\mathrm{P}$ & $\mathrm{P}$ \\
\hline C11 & 43 & Retroperitoneum & Hyaline vascular, stromal-rich & 8.5 & NI & $\mathrm{M}$ & $\mathrm{M}$ & $\mathrm{P}$ & $\mathrm{P}$ \\
\hline C12 & 14 & Mediastinum & Hyaline vascular, stromal-rich & 14.0 & NI & $\mathrm{M}$ & $\mathrm{M}$ & $\mathrm{P}$ & $\mathrm{P}$ \\
\hline C13 & 30 & Right submandibular & Hyaline vascular, classic & 2.5 & $\mathrm{P}$ & NI & $\mathrm{P}$ & $\mathrm{P}$ & $\mathrm{P}$ \\
\hline
\end{tabular}

Abbreviations: Conv, conventional HUMARA gene analysis; E, equivocal; M, monoclonal; NA, not available; NI, non-informative; P, polyclonal.

genes and the T-cell receptor $\gamma$ and $\beta$ genes, as described in our previous study. ${ }^{21}$

\section{Conventional Cytogenetic Analysis}

Conventional cytogenetic analysis was performed in three cases (case N5 and two additional males) of hyaline vascular Castleman disease to test any cytogenetic abnormalities. All the three cases showed no evidence of stromal overgrowth. The G-banding method was used and two cases had been reported previously. ${ }^{16}$

\section{Statistical Analysis}

Appropriate statistical tests were used to examine the relationships and correlations between variables, including Student $t$-test, and $\chi^{2}$-test or Fisher's exact test. The $P$-value referred to is two-sided. The analyses were carried out using SPSS 13.0 statistical software (SPSS, Chicago, IL, USA).

\section{Results}

\section{Female Cases of Hyaline Vascular Castleman Disease}

The study group included 29 patients with hyaline vascular Castleman disease (Table 1) with a mean age of 32.8 years (range, 5-65 years). All cases received total or partial excision. These patients were followed for a mean of 40 months (range, 0.4-120.5 months). All 29 cases of hyaline vascular Castleman disease as well as a comparison group of three cases of plasma cell Castleman disease were negative for immunostaining of HHV-8 latent nuclear antigen. Persistent disease was found in 4 of 23 
Table 2 Summary of clinicopathologic features of hyaline vascular Castleman disease

\begin{tabular}{|c|c|c|c|c|c|c|c|c|}
\hline \multirow[b]{2}{*}{ Parameter } & \multirow[b]{2}{*}{ Case no. } & \multicolumn{4}{|c|}{ HUMARA gene analysis } & \multirow[b]{2}{*}{$\mathrm{P}\left(\chi^{2}\right.$-test $)$} & \multirow{2}{*}{$\begin{array}{c}\text { Age (years) } \\
\text { (mean) }\end{array}$} & \multirow{2}{*}{$\begin{array}{c}\text { Persistent } \\
\text { disease }^{\mathrm{a}}\end{array}$} \\
\hline & & $M$ & $P$ & NI & $M$ rate & & & \\
\hline Type & & & & & & 0.452 & & \\
\hline Hyaline vascular & 29 & 22 & 6 & 1 & $79 \%$ & & 32.8 & \\
\hline Classical & 13 & 9 & 4 & 0 & $69 \%$ & & 30.6 & 1 \\
\hline Lymphoid & 4 & 3 & 1 & 0 & $75 \%$ & & 32.3 & 1 \\
\hline Stromal-rich & 12 & 10 & 1 & 1 & $91 \%$ & & 35.4 & 2 \\
\hline Plasma cell & 3 & 3 & 0 & 0 & $100 \%$ & & 40.3 & \\
\hline Age (years) & & & & & & 0.357 & & \\
\hline$<32.8$ & 15 & 10 & 4 & 1 & $71 \%$ & & 20.1 & 1 \\
\hline$>32.8$ & 14 & 12 & 2 & 0 & $86 \%$ & & 46.5 & 3 \\
\hline Lesion site & & & & & & 0.468 & & \\
\hline Peripheral & 15 & 11 & 4 & 0 & $73 \%$ & & 31.6 & 2 \\
\hline Central & 14 & 11 & 2 & 1 & $85 \%$ & & 34.1 & 2 \\
\hline Lesion size $(\mathrm{cm})$ & & & & & & 0.034 & & \\
\hline$\leqq 5$ & 13 & 8 & 5 & 0 & $62 \%$ & & 27.9 & 2 \\
\hline$>5$ & 10 & 9 & 0 & 1 & $100 \%$ & & 33.4 & 2 \\
\hline Stromal proliferation & & & & & & 0.208 & & \\
\hline Absent & 26 & 19 & 6 & 1 & $76 \%$ & & 32.0 & 4 \\
\hline Present & 3 & 3 & 0 & 0 & $100 \%$ & & 39.7 & 0 \\
\hline
\end{tabular}

Abbreviations: M, monoclonal; $\mathrm{M}$ rate, monoclonal rate; NI, non-informative; P, polyclonal.

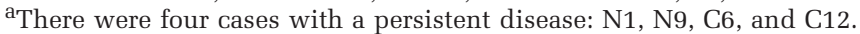

Bold indicates significant $P<0.05$ value.

$(17 \%)$ cases of hyaline vascular Castleman disease (Table 2).

\section{HUMARA Gene Analysis and Immunoglobulin and T-Cell Receptor Gene Rearrangement}

The results are listed in Table 1. In hyaline vascular Castleman diseases with informative results, conventional HUMARA analysis (Figure 2a) showed a monoclonal pattern in 10 of $19(53 \%)$ cases, and methylation-specific PCR HUMARA analysis (Figure 2b) yielded a monoclonal pattern in 17 of $23(74 \%)$ cases. The overall positive rate for monoclonality was $79 \%(22 / 28)$ (Table 2). The monoclonal rates for three variants of hyaline vascular Castleman disease were: classical 69\%, lymphoid $75 \%$, and stromal-rich $91 \%$. Interestingly, along with the incremental increase in the frequency of monoclonality, the mean age for the three variants of hyaline vascular Castleman disease was also increased: classical 30.6 years, lymphoid 32.3 years and stromal-rich 35.4 years (Table 2). Although the monoclonal rate was higher for lesions in older patients, in central lymph nodes, and with stromal proliferations (cases N7, M3, and M7), only larger lesion size $(>5 \mathrm{~cm})$ showed statistical significance $(P=0.034$; Table 2). In comparison, all LH cases with informative results showed a polyclonal pattern of HUMARA gene (Supplementary Table S1 and Supplementary Figure S1).

In contrast to the frequent monoclonality for HUMARA gene, all 29 cases of hyaline vascular Castleman disease were negative for monoclonal immunoglobulin and T-cell receptor gene rearrangements (Table 1). One case of plasma cell Castleman disease (C4) was positive for monoclonal immunoglobulin gene rearrangements (Supplementary Figure S2). The other two cases lacked immunoglobulin gene rearrangements and all three were negative for T-cell receptor gene rearrangements. All LH cases were negative for B- and T-cell clonality except one (LH10) being equivocal for immunoglobulin gene rearrangement (Supplementary Table S1).

\section{Conventional Cytogenetic Analysis}

Conventional cytogenetic studies were carried out for three cases (N5 and two male patients, 39 and 45 years), which showed no evidence of stromal overgrowth. Two of them showed cytogenetic abnormalities with $t(1 ; 22)(p 22 ; q 13)$ and $t(7 ; 8)(q t e r ; q 12)$ in each (Figure 3 ).

\section{Discussion}

In this study, we provide evidence that most cases of hyaline vascular Castleman disease are monoclonal when assessed by HUMARA gene analysis, but no cases had monoclonal immunoglobulin or T-cell receptor gene rearrangements. Interestingly, this monoclonal HUMARA gene pattern was more frequently found in larger lesions $(>5 \mathrm{~cm})$, in stromal-rich variant, and in lesions with stromal overproliferations. In addition, two cases without 


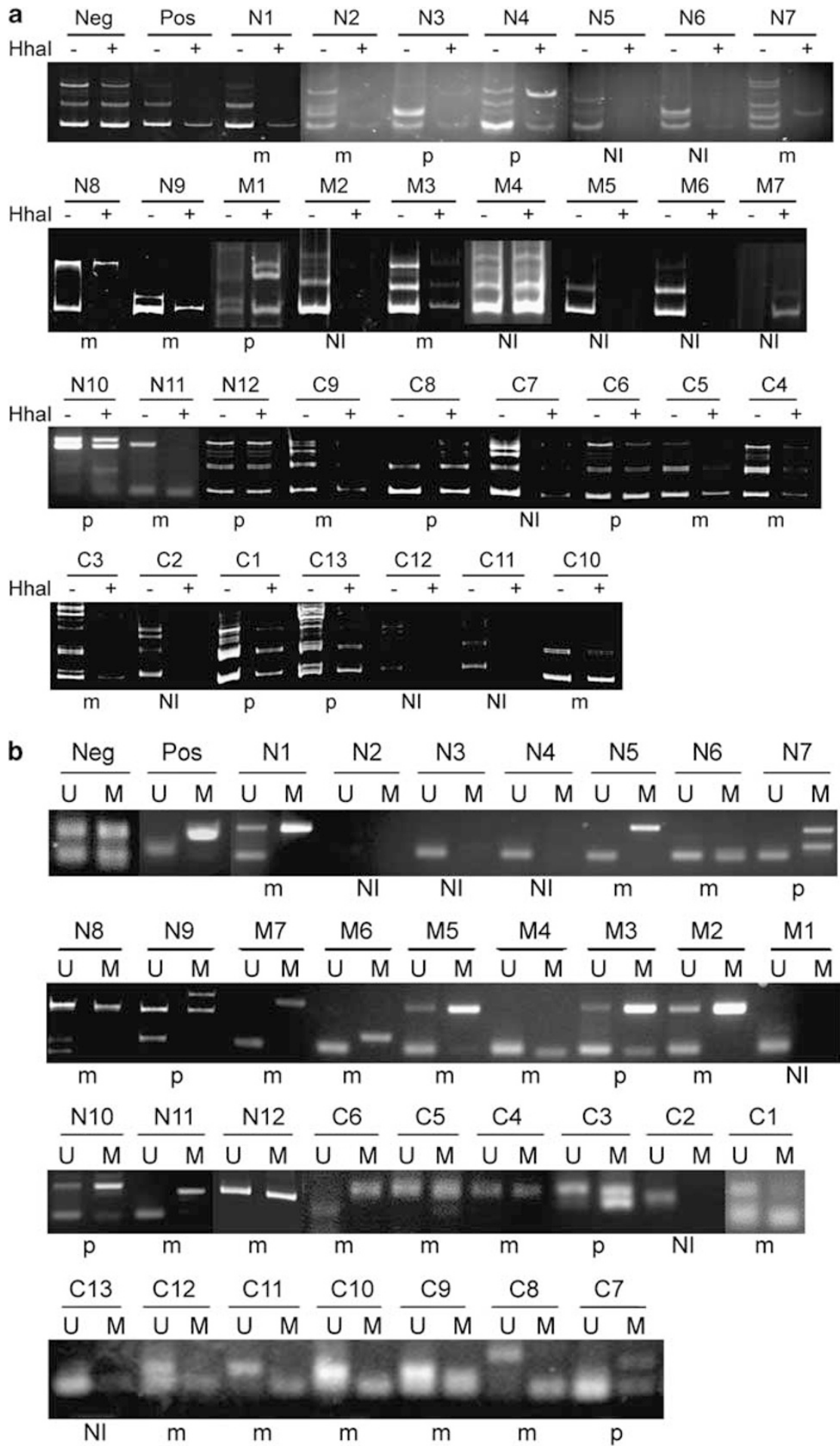

Figure 2 Conventional (a) and methylation-specific PCR (b) HUMARA gene analyses for Castleman disease. There are total 32 cases of Castleman disease (N1-N12, M1-M7, and C1-C13) with hyaline vascular type in 29 and plasma cell type in 3 (N8, M2, and C4). In hyaline-vascular-type cases with informative results (see Table 1 for details), conventional HUMARA analysis (a) shows a monoclonal pattern in 10 of 19 (53\%) cases and methylation-specific PCR HUMARA analysis (b) yields a monoclonal pattern in 17 of 23 (74\%) cases. Neg, negative control; Pos, positive control; - , no digestion; +, digested with HhaI; U, PCR products amplified with primers specific for unmethylated DNA; M, PCR products amplified with primers specific for methylated DNA. The results, labeled m (monoclonal), $\mathrm{p}$ (polyclonal), and NI (non-informative) were repeated in triplicate, especially for NI cases.

stromal overgrowth carried cytogenetic anomalies. These findings suggest that hyaline vascular Castleman disease is a monoclonal proliferative lesion.
Although monoclonality is not equal to neoplasia, it is an early event in the multistep neoplastic process, ${ }^{19}$ and therefore the findings suggest that 
a

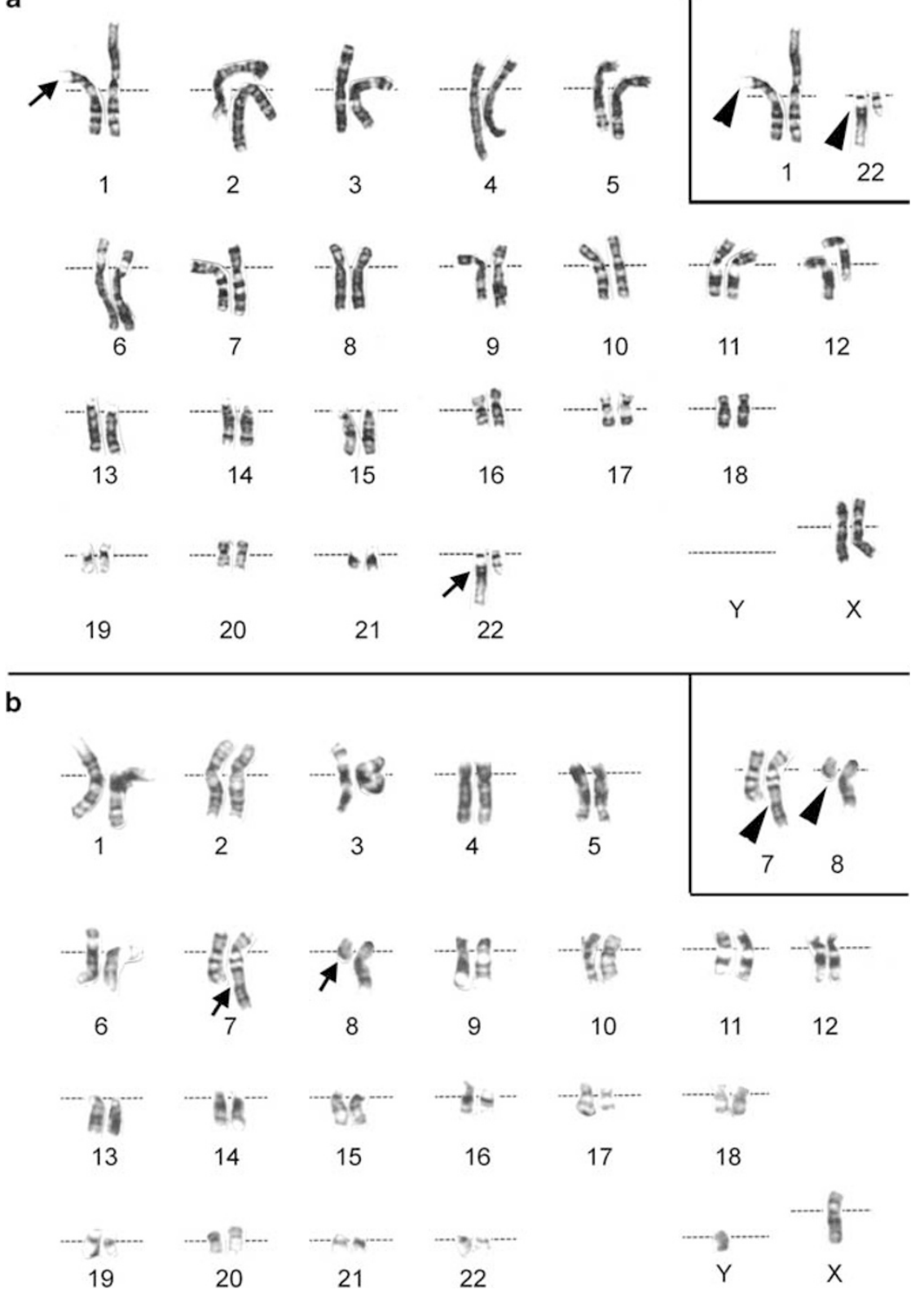

Figure 3 Cytogenetic anomalies in hyaline vascular Castleman's disease. G-banded analysis reveals abnormal karyotypes, $\mathrm{t}(1 ; 22)(\mathrm{p} 22 ; \mathrm{q} 13)$ in case N5 (a) and $\mathrm{t}(7 ; 8)(\mathrm{qter} ; \mathrm{q} 12)$ in another male case (b) in short-term cultured cells. The translocations are indicated by arrows and on the upper right in pair (inset).

hyaline vascular Castleman disease is a benign neoplasm, which has been favored by few authors. ${ }^{22,23}$ This suggestion is in contrast to traditional ideas about the pathogenesis of hyaline vascular Castleman disease, which is largely unknown but regarded to be most likely hyperplastic or hamartomatous in nature. ${ }^{9,12}$

Hyaline vascular Castleman diseases with genetic anomalies have been reported previously (Supplementary Table S2) and the cell origin responsible for the abnormal genetics has been demonstrated directly or indirectly to be stromal cells, either follicular dendritic cells or actin-positive myoid cells. ${ }^{14-16}$ Hyaline vascular Castleman disease is composed of proliferating lymphoid cells and stromal cells. Provided that it is monoclonal and neoplastic, the tumor cells would be lymphoid or stromal cells. As the immunoglobulin and T-cell receptor genes are in germline status, it indicates that the stromal cells would be the culprit. In support of this, subsequent development of stromal tumors has been repeatedly reported in hyaline vascular Castleman disease, usually originating from follicular dendritic cells, vascular cells, myoid cells, and fibrohistiocytic cells. $5,10,24-27$ Furthermore, hyaline vascular Castleman disease is well known to be associated with paraneoplastic pemphigus, a syndrome typically occurring in 
tumor patients. ${ }^{28-30}$ It appears that hyaline vascular Castleman disease shares some neoplastic features.

The histogenesis of stromal overgrowth in hyaline vascular Castleman disease is commonly considered secondary. ${ }^{10}$ However, the findings of genetic changes preceding the morphologically stromal overgrowth may elicit the idea that the genetic alteration of stromal cells is a leading event in hyaline vascular Castleman disease. The compressed sinuses are a characteristic feature of hyaline vascular Castleman disease and are probably related to stromal proliferation. The compressed sinuses result in the lymph node being a closed system that sequesters soluble factors or cytokines in the lymph node that could subsequently lead to overgrowth of stromal cells. ${ }^{31-33}$ As hyaline vascular Castleman diseases of larger size and with stromal overgrowth were monoclonal in almost all cases, it indicates that the monoclonal proliferation of stromal cells become more prominent with time.

The HUMARA gene analysis is the most widely used method for the determination of X-chromosome inactivation, which has been the standard method to assay the clonal nature for lesions in female patients. ${ }^{19}$ In addition to the conventional HUMARA gene analysis described by Allen et al, ${ }^{18}$ some other methods have also been reported, such as the methylation-specific PCR HUMARA assay. ${ }^{20}$ This assay can minimize the false polyclonality resulting from incomplete DNA digestion by methylation-sensitive restriction enzymes. Accordingly, we found that methylation-specific PCR HUMARA assay increased the monoclonal rate by $21 \%$. The remaining cases with non-informative results may result from the degradation of nucleic acids or effects of fixatives in paraffin-embedded tissue. ${ }^{19,34}$ We have monitored the efficiency of HhaI enzyme digestion and ensured the validity of our results by measuring XE169 gene amplification, as described previously (Supplementary Figure S3). ${ }^{19}$

In conclusion, our results show that most cases of hyaline vascular Castleman disease are monoclonal proliferations, most likely of stromal cell origin, as the lymphoid cells are polyclonal. Some cases are associated with conventional cytogenetic anomalies. On the basis of the well-known clinical behavior of patients with hyaline vascular Castleman disease, this lesion is therefore a benign neoplasm of lymph node stromal cells, although rare cases can undergo progression to neoplastic stromal cell neoplasms. We believe our study has shed light on the pathogenesis of hyaline vascular Castleman disease.

\section{Acknowledgments}

This study was supported by grants from the Taiwan National Science Council (NSC100-2320-B-006-005MY3) and Department of Health, Executive Yuan, Taiwan (DOH101-TD-C-111-003: to establish centers of excellence for cancer research in Taiwan) to KC
Chang, and a grant from the National Cheng Kung University Hospital, Taiwan (NCKUH-10002020) to LY Kao. This study was presented in poster format at the United States and Canadian Academy of Pathology (USCAP) 2012 Annual Meeting, 17-23 March 2012, Vancouver, BC, Canada.

\section{Disclosure/conflict of interest}

The authors declare no conflict of interest.

\section{References}

1 Castleman B, Iverson L, Menendez VP. Localized mediastinal lymphnode hyperplasia resembling thymoma. Cancer 1956;9:822-830.

2 Keller AR, Hochholzer L, Castleman B. Hyalinevascular and plasma-cell types of giant lymph node hyperplasia of the mediastinum and other locations. Cancer 1972;29:670-683.

3 Soulier J, Grollet L, Oksenhendler E, et al. Kaposi's sarcoma-associated herpesvirus-like DNA sequences in multicentric Castleman's disease. Blood 1995;86: 1276-1280.

4 Ioachim H, Medeiros LJ. Ioachim's Lymph Node Pathology, 4th edn. Lippincott Williams \& Wilkins: Philadelphia, PA, USA; 2009, p 227.

5 Cronin DM, Warnke RA. Castleman disease: an update on classification and the spectrum of associated lesions. Adv Anat Pathol 2009;16:236-246.

6 Parravicini C, Corbellino M, Paulli M, et al. Expression of a virus-derived cytokine, KSHV vIL-6, in HIVseronegative Castleman's disease. Am J Pathol 1997; 151:1517-1522.

7 Schulte KM, Talat N. Castleman's disease-a two compartment model of HHV8 infection. Nat Rev Clin Oncol 2010;7:533-543.

8 Rosai J. Rosai and Ackerman's Surgical Pathology Vol. II10th edn. Mosby: Philadelphia, PA, USA; 2011, p 1796.

9 Frizzera G. Castleman's disease and related disorders. Semin Diagn Pathol 1988;5:346-364.

10 Lin O, Frizzera G. Angiomyoid and follicular dendritic cell proliferative lesions in Castleman's disease of hyaline-vascular type: a study of 10 cases. Am J Surg Pathol 1997;21:1295-1306.

11 Danon AD, Krishnan J, Frizzera G. Morpho-immunophenotypic diversity of Castleman's disease, hyalinevascular type: with emphasis on a stroma-rich variant and a new pathogenetic hypothesis. Virchows Arch A 1993;423:369-382.

12 Nguyen DT, Diamond LW, Hansmann ML, et al. Castleman's disease. Differences in follicular dendritic network in the hyaline vascular and plasma cell variants. Histopathology 1994;24:437-443.

13 Ruco LP, Gearing AJ, Pigott R, et al. Expression of ICAM-1, VCAM-1 and ELAM-1 in angiofollicular lymph node hyperplasia (Castleman's disease): evidence for dysplasia of follicular dendritic reticulum cells. Histopathology 1991;19:523-528.

14 Pauwels P, Dal Cin P, Vlasveld LT, et al. A chromosomal abnormality in hyaline vascular Castleman's disease: evidence for clonal proliferation of dysplastic stromal cells. Am J Surg Pathol 2000;24:882-888. 
15 Cokelaere K, Debiec-Rychter M, De Wolf-Peeters C, et al. Hyaline vascular Castleman's disease with HMGIC rearrangement in follicular dendritic cells: molecular evidence of mesenchymal tumorigenesis. Am J Surg Pathol 2002;26:662-669.

16 Chen WC, Jones D, Ho CL, et al. Cytogenetic anomalies in hyaline vascular Castleman disease: report of two cases with reappraisal of histogenesis. Cancer Genet Cytogenet 2006;164:110-117.

17 Tsai JW, Tsou JH, Hung LY, et al. Combined ErdheimChester disease and Langerhans cell histiocytosis of skin are both monoclonal: a rare case with human androgen-receptor gene analysis. J Am Acad Dermatol 2010;63:284-291.

18 Allen RC, Zoghbi HY, Moseley AB, et al. Methylation of HpaII and HhaI sites near the polymorphic CAG repeat in the human androgen-receptor gene correlates with X chromosome inactivation. Am J Hum Genet 1992;51:1229-1239.

19 van Dijk JP, Heuver LH, van der Reijden BA, et al. A novel, essential control for clonality analysis with human androgen receptor gene polymerase chain reaction. Am J Pathol 2002;161:807-812.

20 Uchida T, Ohashi H, Aoki E, et al. Clonality analysis by methylation-specific PCR for the human androgenreceptor gene (HUMARA-MSP). Leukemia 2000;14: 207-212.

21 Chen YL, Su IJ, Cheng HY, et al. BIOMED-2 protocols to detect clonal immunoglobulin and T-cell receptor gene rearrangements in $\mathrm{B}$ - and T-cell lymphomas in southern Taiwan. Leuk Lymphoma 2010;51:650-655.

22 Fisher ER, Sieracki JC, Goldenberg DM. Identity and nature of isolated lymphoid tumors (so-called nodal hyperplasia, hamartoma, and angiomatous hamartoma) as revealed by histologic, electron microscopic, and heterotransplantation studies. Cancer 1970;25: 1286-1300.

23 Zettergren L. Probably neoplastic proliferation of lymphoid tissue (follicular lympho-reticuloma). Reports of four cases with a survey of literature. Acta Pathol Microbiol Scand 1961;51:113-126.

24 Chan JK, Tsang WY, Ng CS. Follicular dendritic cell tumor and vascular neoplasm complicating hyaline-vascular Castleman's disease. Am J Surg Pathol 1994;18:517-525.

25 Gerald W, Kostianovsky M, Rosai J. Development of vascular neoplasia in Castleman's disease. Report of seven cases. Am J Surg Pathol 1990;14:603-614.

26 Izumi M, Mochizuki M, Kuroda M, et al. Angiomyoid proliferative lesion: an unusual stroma-rich variant of Castleman's disease of hyaline-vascular type. Virchows Arch 2002;441:400-405.

27 Kurotaki H, Kaimori M, Nagai K. Recurred Castleman’s disease containing a fibrohistiocytic nodular lesion with vascular occlusion. Acta Pathol Jpn 1993;43: 603-607.

28 Fang Y, Zhao L, Yan F, et al. A critical role of surgery in the treatment for paraneoplastic pemphigus caused by localized Castleman's disease. Med Oncol 2010; 27:907-911.

29 Kaplan I, Hodak E, Ackerman L, et al. Neoplasms associated with paraneoplastic pemphigus: a review with emphasis on non-hematologic malignancy and oral mucosal manifestations. Oral Oncol 2004;40: $553-562$.

30 Nikolskaia OV, Nousari CH, Anhalt GJ. Paraneoplastic pemphigus in association with Castleman's disease. $\mathrm{Br}$ J Dermatol 2003;149:1143-1151.

31 Kakiuchi C, Ishida $\mathrm{T}$, Sato $\mathrm{H}$, et al. Secretion of interleukin-6 and vascular endothelial growth factor by spindle cell sarcoma complicating Castleman's disease (so-called 'vascular neoplasia'). J Pathol 2002; 197:264-271.

32 Miltenyi Z, Toth J, Gonda A, et al. Successful immunomodulatory therapy in castleman disease with paraneoplastic pemphigus vulgaris. Pathol Oncol Res 2009;15:375-381.

33 Seida A, Wada J, Morita Y, et al. Multicentric Castleman's disease associated with glomerular microangiopathy and MPGN-like lesion: does vascular endothelial cell-derived growth factor play causative or protective roles in renal injury? Am J Kidney Dis 2004;43:E3-E9.

34 Jung A, Ruckert S, Frank P, et al. 7-Deaza-2'-deoxyguanosine allows PCR and sequencing reactions from CpG islands. Mol Pathol 2002;55:55-57.

Supplementary Information accompanies the paper on Modern Pathology website (http://www.nature.com/ modpathol) 